\title{
Fold interference patterns in Meso-Proterozoic Champaner fold belt (CFB) Gujarat, western India
}

\author{
ADITYA U JOSHI \\ Department of Geology, Faculty of Science, The Maharaja Sayajirao University of Baroda, \\ Vadodara, Gujarat 390 002, India. \\ e-mail: adityaujoshi@gmail.com
}

MS received 7 December 2017; revised 16 February 2018; accepted 12 May 2018; published online 23 February 2019

This paper documents three phases of folding within the Meso-Proterozoic Champaner Fold Belt (CFB) located at the eastern part of Gujarat, western India. The first phase $\left(\mathrm{F}_{1}\right)$ displays WNW plunging $\mathrm{F}_{1}$ fold of moderately inclined nature in the schists of the Khandia Formation. The second phase $\left(\mathrm{F}_{2}\right)$ refolded $\mathrm{F}_{1}$ along a similar trend to produce folds of tight isoclinal nature in the Khandia and Narukot quartzites. Additionally, these $F_{1}$ folds depict second-order tight, and $\mathrm{F}_{2}$ folds as first-order open type in the younger sequences of the CFB with varying amplitude vs. wavelength ratio. The ratio for $\mathrm{F}_{1}$ folds ranges from 2:1 to 3:1, obtained along $3-4 \mathrm{~m}$ length across 3-6 $\mathrm{m}^{2}$ area, whereas for $\mathrm{F}_{2}$ folds the ratio ranges from 1:4 to 1:5 and is obtained along 1-2.5 km length across $0.5-1.5 \mathrm{~km}^{2}$ area. The fold interference pattern developed on account of $\mathrm{F}_{1}$ and $\mathrm{F}_{2}$ folds has resulted into Type-III or hook-shaped geometry regionally. The last phase of folding is characterised by $\mathrm{N}-\mathrm{S}$ trending $\mathrm{F}_{3}$ folds of open type over kilometre long limbs of $\mathrm{F}_{1}$ and $\mathrm{F}_{2}$ folds. The superposition of $\mathrm{F}_{1-3}$ folds developed map scale Type-I or Dome and Basin geometry over Type-III superposed folds. The overall compressional direction for $\mathrm{F}_{1}$ and $\mathrm{F}_{2}$ folds ranges from N-S to NNE-SSW and for $\mathrm{F}_{3}$ ranges from E-W to ESE-WNW.

Keywords. Champaner Fold Belt (CFB); Narukot; interference fold pattern; hook shaped; dome and basin.

\section{Introduction}

In any area, the existence of interference fold patterns indicates refolding of earlier folds. A derivative of these interference geometries ranges from micro- to mega-scale (see, e.g., Platt 1983; Ghosh 1993; Fossen and Holst 1995; Mamtani et al. 2001; Caritg et al. 2004; Tian et al. 2013; Fossen 2016). The interference geometries are important as they provide significant clues on shortening direction and decode the multiple deformational events (Forbes and Betts 2004; Forbes et al. 2004). A combination of such refolded folds on map scale has been documented in the present work with the aid of detailed fieldwork.

The area under investigation is the part of Southern Aravalli Mountain Belt (SAMB) exposed along the eastern fringe of Gujarat, India (figure 1a). Rocks of this region belong to the Champaner Group of Meso-Proterozoic age, forming the youngest part of the Aravalli Supergroup (Gupta et al. 1992, 1995, 1997). Initially, the structural history of the Champaner Group was thought to be very simple with respect to the main Aravalli domain. The idea proposed by Roy $(1985,1988)$ and Merh (1995) suggests that the Champaner 


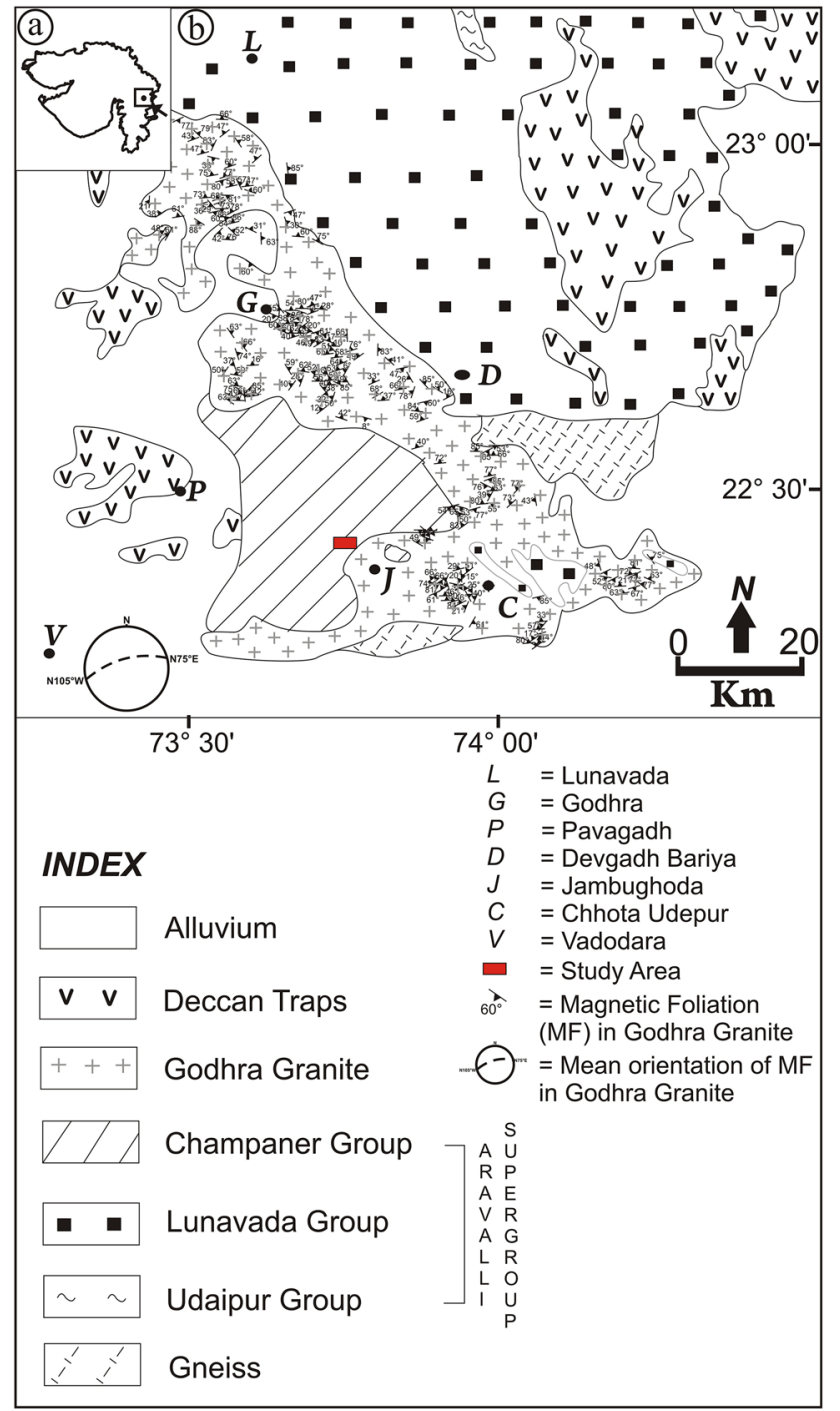

Figure 1. (a) Location sketch of the Champaner Group; (b) lithostratigraphic map of SAMB, NW, India. Modified after Mamtani and Greiling (2005). Red square indicates the study area. Magnetic foliation data presented within Godhra granite is after Mamtani (2014).

Group represents one single phase of deformation and possesses no superposed folds. Later on the detailed work carried out by Karanth and Das (2000) and Das (2003) in order to decode the deformational history of the Pre-Champaner Gneissic Complex in Chhota Udepur region gave a comparative study about the deformational style between Pre-Champaners and Champaner rocks. They illustrated two phases of folding within the Champaner Group having orthogonal axial planes. However, they did not comment on the existence of superposed folds within the Champaner Group of rocks, unlike that in the Pre-Champaner Gneissic Complex of Chhota Udepur region. In the light of hitherto work, more research is needed in order to address the structural complexity in the form of interference fold pattern within the rocks of the Champaner Group.

\section{Geological setting}

The Champaner Fold Belt, consists of the Champaner Group, is a part of upper Aravalli exposed along the southern most fringe of SAMB in Gujarat (Gupta et al. 1992, 1995) (figure 1b). The Champaner Group is characterised by MesoProterozoic low-grade metasedimentary rocks and are intruded by Neo-Proterozoic $(955 \pm 20$ Ma) Godhra granite (Rb/Sr method; Gopalan et al. 1979). Lithologically, it comprises metasubgraywacke, phyllite, carbonaceous schist, quartzite, gneisses and petromict metaconglomerate with bands of dolomitic limestone and mangeniferous phyllite (Gupta et al. 1980, 1997) (figure 2a). Based on the homogeneity in terms of rock type, strike persistency and occurrence of intraformational conglomerate, the Champaner Group has been divided into six formations (Gupta et al. 1997) (table 1; Gupta et al. 1980, 1992). Greenschist facies condition demarcates the regional grade of metamorphism, whereas the contact metamorphic grade has reached up to the hornblende hornfels facies (Jambusaria and Merh 1967; Jambusaria 1970; Gupta et al. 1997; Das 2003; Das et al. 2009).

\section{Structural setup}

The existing structural set up of the Champaner Group suggests that the rocks are polydeformed forming a regional ' $\mathrm{S}$ ' shaped pattern consisting two major anticlines and synclines (Jambusaria 1970). Two phases of deformation have been recorded so far, viz., $\mathrm{D}_{1}$ : $\mathrm{E}-\mathrm{W}$ trending $\mathrm{F}_{1}$ folds of tight/isoclinal upright nature; and $\mathrm{D}_{2}: \mathrm{N}-\mathrm{S}$ trending $\mathrm{F}_{2}$ folds with $\mathrm{N}$ plunging open warps with kink bands (Jambusaria and Merh 1967; Gopinath et al. 1977; Shah et al. 1984; Srikarni and Das 1996; Karanth and Das 2000; Das 2003; Limaye and Bhatt 2013; Limaye 2016a, b; Patel et al. 2016). $\mathrm{F}_{1}$ and $\mathrm{F}_{2}$ folds are also affected by numerous axial planar slippages depicting radial pattern (Jambusaria and Merh 1967; Yellur 1969; Jambusaria 1970; Joshi et al. 2018). The axial planar slippages scattered in a radial pattern show signatures of sinistral/dextral faults (figure 2a). Moreover, there also exists signature of top-to-east cross-sectional 


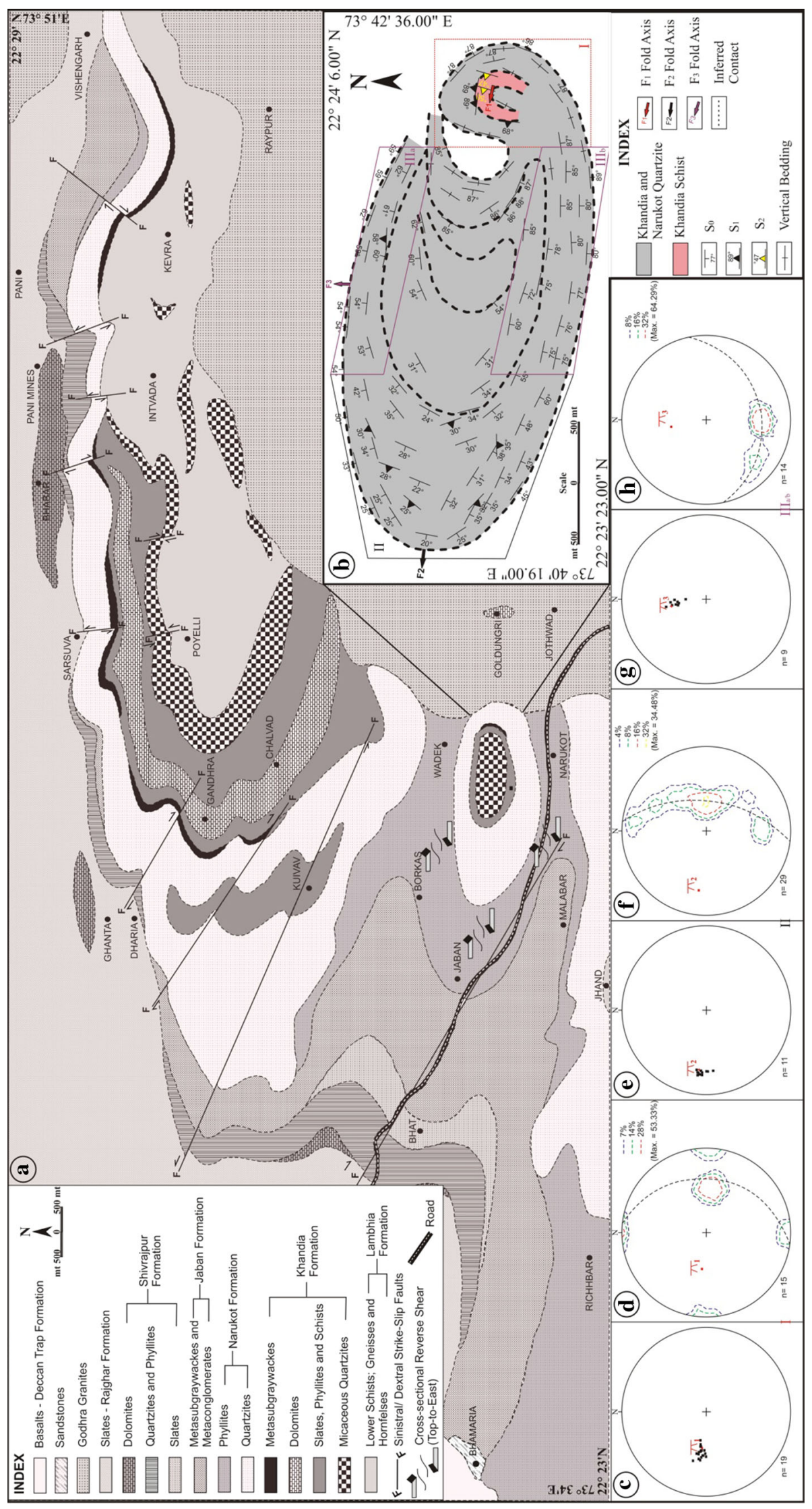

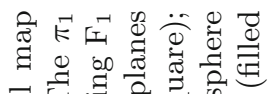

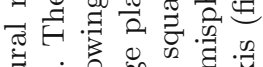

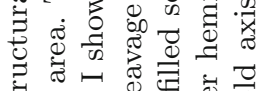

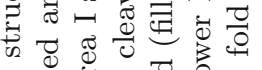

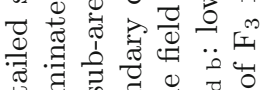

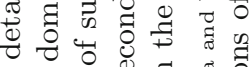

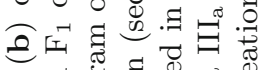

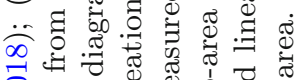

藏者.

उ

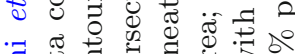

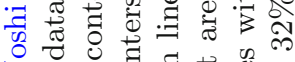

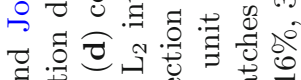

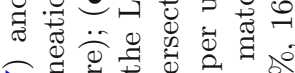

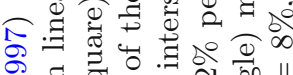

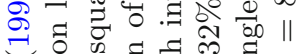

子ं

凹

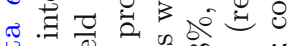

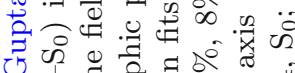

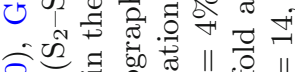

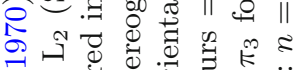

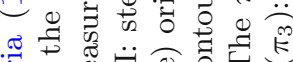

㟧 㟧

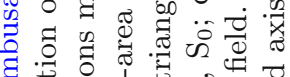

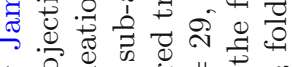

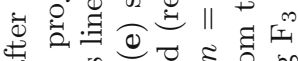

品

ठ․

च 500.4 .

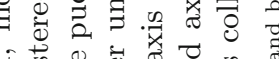

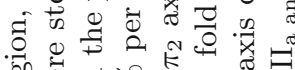

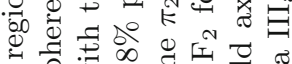

-

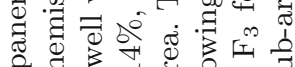

द्व

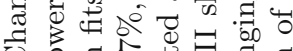

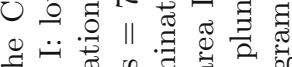

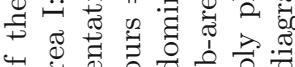

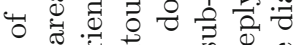

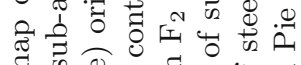
घ के

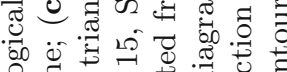

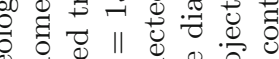

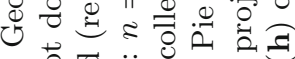

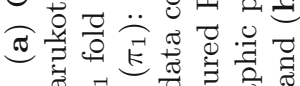

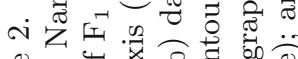

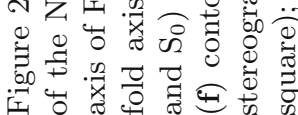


Table 1. Proterozoic stratigraphic succession of Gujarat and south Rajasthan; after Gupta et al. (1980, 1992).

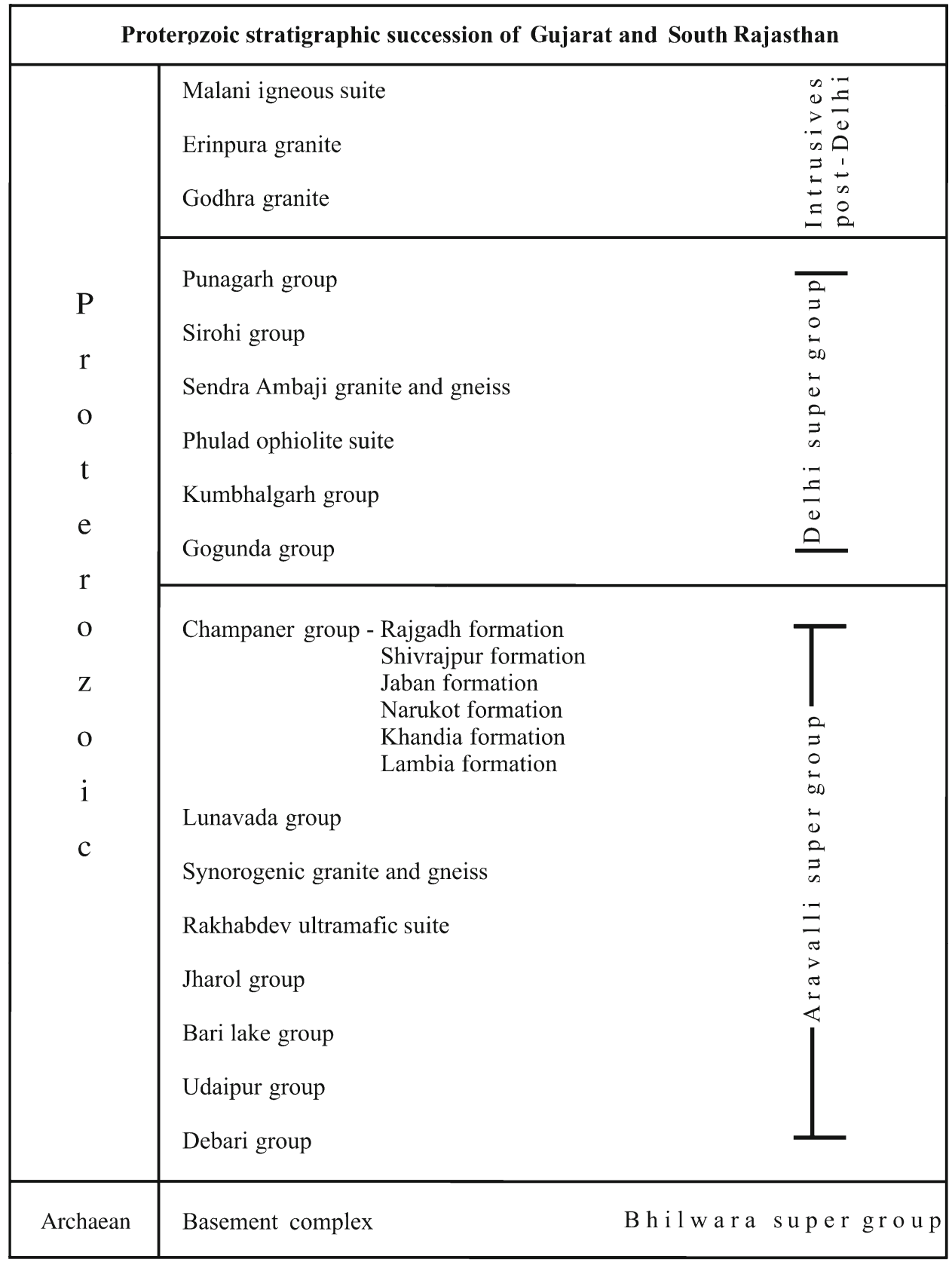

Gupta et al $(1980,1992)$

reverse shears within the rocks of the Narukot Formation (figure 2a) (Joshi et al. 2018). A combination of $F_{1}$ and $F_{2}$ folds along the $E$ margin of the Champaner Group has generated interesting dome structures at Narukot and Poyli areas (Jambusaria 1970). One such dome situated at Narukot within the Khandia and Narukot Formation has been worked out in detail, which provides significant insight in terms of overall deformation undergone by the Champaner Group of rocks.
Regional-scale fold mapping carried out at the 'Narukot dome' differs from the existing structural set up presented by the earlier workers. Dome appearance at Narukot is composed of the combination of $F_{1}$ to $F_{3}$ folds regionally (figure $2 b$ ). In order to carry out the structural analysis the area has been divided into sub-areas, i.e., I, II, $\mathrm{III}_{\mathrm{a}}$ and $\mathrm{III}_{\mathrm{b}}$, representing $\mathrm{F}_{1}, \mathrm{~F}_{2}$ and $\mathrm{F}_{3}$ dominated regions, respectively. Sub-area I represents $\mathrm{F}_{1}$ fold with an axial trace dipping due WNW 

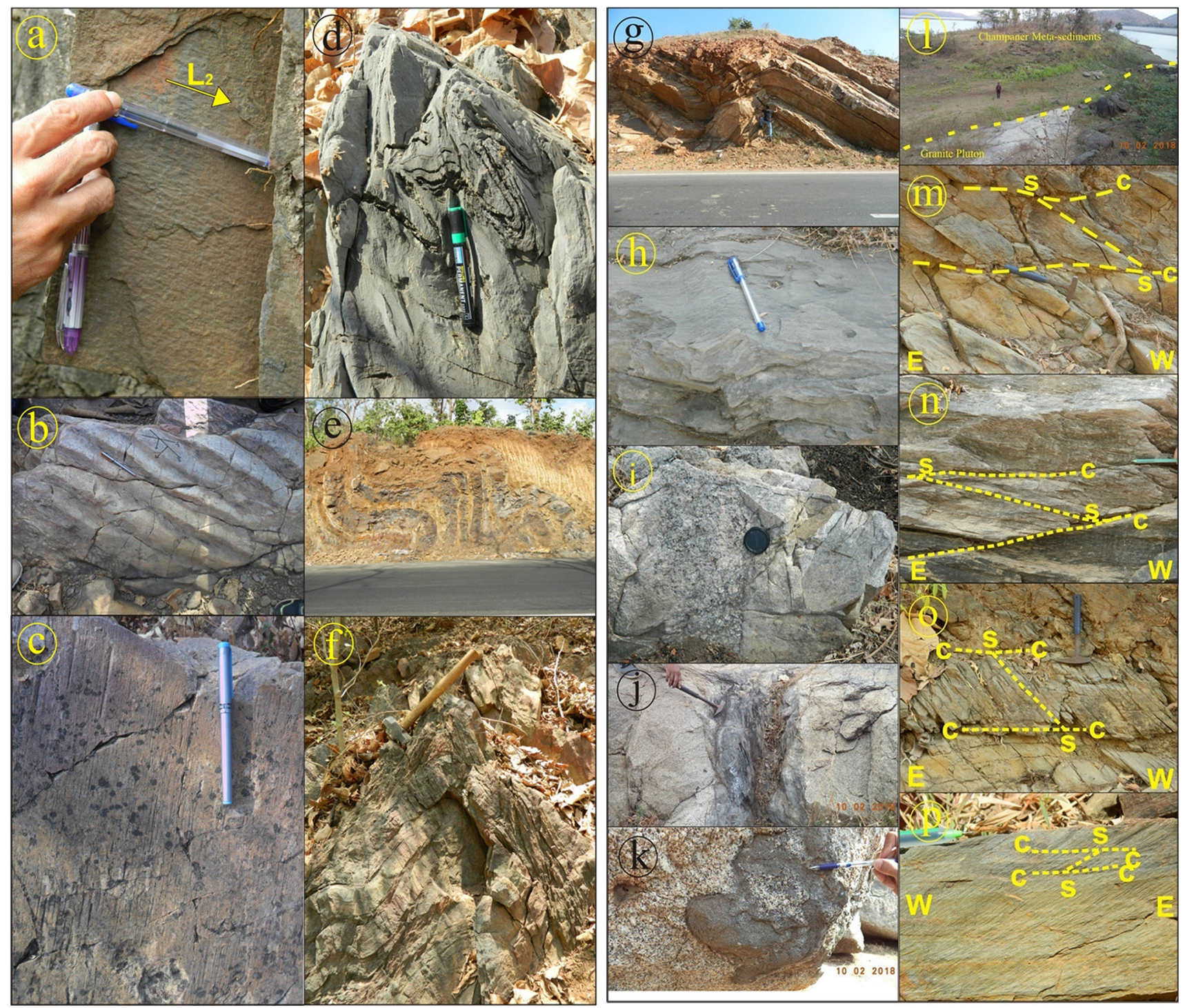

Figure 3. (a) $\mathrm{L}_{2} \quad\left(\mathrm{~S}_{2}-\mathrm{S}_{0}\right)$ intersection lineation in schist of Khandia Formation (camera faces southern direction); (b) sub-parallel relationship between $\mathrm{S}_{0}$ and $\mathrm{S}_{1}$ in quartzite demarcated over the outcrop with black pen markings. Discrete secondary cleavages can be appreciated over $\mathrm{S}_{0}$ (camera faces southeastern direction); (c) steep F3 fold axes preserved in quartzite (camera faces southern direction); (d) second-order tight $\mathrm{F}_{1}$ folds in phyllite of Shivrajpur Formation (camera faces western direction); (e) second-order tight $\mathrm{F}_{1}$ folds within the right limb of first-order open $\mathrm{F}_{2}$ fold in quartzite of Shivrajpur Formation (camera faces western direction); (f) second-order tight $\mathrm{F}_{1}$ fold in quartzite of Lambhia Formation (camera faces western direction); (g) first-order $\mathrm{F}_{2}$ fold in quartzite of Rajghar Formation (camera faces eastern direction); (h) N-S trending Kink band in phyllite of Narukot Formation (camera faces northern direction); (i) field photograph after Joshi and Limaye (2014), showing discordant relationship between intruding coarse-grained granite into fine-grained granite (camera faces eastern direction); (j) xenolith of schistose rock within granite (camera faces western direction); (k) xenolith of fine-grained granite in coarse-grained granite (camera faces northern direction); (l) sharp intrusive contact between granite and the Champaner metasediments (camera faces eastern direction); $(\mathbf{m}-\mathbf{p})$ top-to-east ductile shear along the cross-section. S schistosity fabric dipping steeper than the C-plane. Photograph (n-p) after Joshi et al. (2018).

in Khandia schist located at the eastern part of the dome. $\mathrm{F}_{1}$ fold has resulted due to folding of $\mathrm{S}_{0}$ bedding plane by generating $\mathrm{S}_{1}$ schistosity plane. Due to the manifestation of $\mathrm{F}_{2}$ over $\mathrm{F}_{1}, \mathrm{~S}_{0}$ shows sub-parallel relationship with $\mathrm{S}_{1}$ and axial planar $\mathrm{S}_{2}$ schistosity plane has been developed generating $\mathrm{L}_{2}$ lineations on $\mathrm{S}_{0}$ (figure $3 \mathrm{a}$ ). These lineations are intersection lineations formed by $\mathrm{S}_{2}$ $\mathrm{S}_{0}$ intersection, which plunges $46^{\circ}$ in the direction of $279^{\circ} \mathrm{N}$ and form pucker axis over the hinge line. By plotting several such lineations over lower hemisphere stereographic projection, the orientation 
of $\pi_{1}$ axis fits well with the pucker axes lineations obtained from the field (figure 2c). The fold is moderately inclined having pitch of the $\mathrm{F}_{1}$ fold axis $47^{\circ}$ in the direction of $280^{\circ} \mathrm{N}$ (WNW) measured on $\mathrm{S}_{0}$ plane (figure $2 \mathrm{~d}$ ). Tight to isoclinal $\mathrm{F}_{2}$ folds affected quartzite band as $\mathrm{F}_{1}$ folds refolded along a similar trend. In quartzites the $\mathrm{S}_{0}-\mathrm{S}_{1}$ relationship is sub-parallel to each other and $\mathrm{S}_{0}$ dips slightly steeper as compared to $\mathrm{S}_{1}$ (figure $3 \mathrm{~b}$ ). $\mathrm{S}_{2}$ orientation is feeble and mostly appears as discrete cleavages to form $\mathrm{L}_{2}$ intersection lineations between secondary cleavage planes and $S_{0}$ over $S_{1} \cdot \pi_{2}$ axis of $F_{2}$ fold matches with the data set of intersection lineations recorded from $\mathrm{F}_{2}$ dominated area (figure 2e). The core of the $\mathrm{F}_{2}$ fold is traceable for $1 \mathrm{~km}$ at the western margin of the Narukot dome and can be seen in sub-area II of figure $2 \mathrm{~b}$. The $\mathrm{N}$ and the $\mathrm{S}$ limb of $\mathrm{F}_{2}$ strike $\sim \mathrm{E}-\mathrm{W}$ having due $\mathrm{N}$ and due $\mathrm{S}$ dip directions, respectively. The fold axis plunges towards $\mathrm{W}$ with an amount of $20^{\circ}$ and possess a sub-vertical axial plane (figure 2f). Sub-area $\mathrm{III}_{\mathrm{a}, \mathrm{b}}$ depicts $\mathrm{F}_{3}$ open fold trending $\mathrm{N}-\mathrm{S}$ axial trace over kilometre long limbs of $\mathrm{F}_{1}$ and $\mathrm{F}_{2}$ folds. The axial plane can be traced from the $\mathrm{N}$ to the $\mathrm{S}$ fringe of the dome dividing it into two approximately equal portions. Steeply dipping mesoscopic $\mathrm{F}_{3}$ fold axes have been observed along outer rim of quartzite near SW of Wadek (figure 3c). These lineations fit well with the fold axis $\pi_{3}$ (figure $2 \mathrm{~g}$ ). The folds possess vertical axial plane and have a northerly plunge of its axis (figure 2h). Representation of $\mathrm{F}_{1-3}$ folds along with the orientation of the axial plane and fold axis in the Narukot dome, depicted by SRTM worldwide elevation data (3-arc-second resolution) downloaded from Global mapper (v17) (figure 4).

An attempt has been made to study the derivates of these three fold events across the Champaner Group. The results signify that further to the W of the Narukot dome, where the younger Formation of the Champaner Group is encountered, $F_{1}$ folds exhibit second-order tight and $F_{2}$ folds as first-order open with varying amplitude vs. wavelength ratio (figure $3 \mathrm{~d}-\mathrm{g}$ ). The ratio for $\mathrm{F}_{1}$ folds has been calculated in the field as the folds are meso-scopic in nature. The ratio ranges from $2: 1$ to $3: 1$, obtained along $3-4 \mathrm{~m}$ length across 3-6 $\mathrm{m}^{2}$ area. However, for $\mathrm{F}_{2}$ folds the ratio ranges from $1: 4$ to $1: 5$, obtained along 1-2.5 km length across $0.5-1.5 \mathrm{~m}^{2}$ area. These $\mathrm{F}_{2}$ fold ratios have been acquired through satellite image and validated during mapping. $F_{3}$ folds gradually die out in the form of mega-scale open wraps to meso-scale kink bands from eastern to the western stretch of the Champaner Group, respectively (figure $3 \mathrm{~h}$ ).

\section{Discussions}

Analyses of individual folds from $F_{1}$ to $F_{3}$ at Narukot were helpful in interpreting the regionalscale deformation interference pattern. The combination of $\mathrm{F}_{1}$ and $\mathrm{F}_{2}$ fold has generated map scale hook or Type-III interference pattern of Ramsay (1962) and Ramsay and Huber (1987), demonstrating a comprehensive hammer head anticlinal structure. Their fold axes are sub-parallel $\left(\mathrm{F}_{1} \sim\right.$ WNW; $\left.\mathrm{F}_{2} \sim \mathrm{W}\right)$ with $\sim$ orthogonal axial planes. Overprinting of $F_{3}$ fold on $F_{1}$ and $F_{2}$ developed regional-scale dome and basin geometry or Type-I interference pattern (Ramsay 1962; Ramsay and Huber 1987). Moreover, $\mathrm{N}-\mathrm{S}$ trending $\mathrm{F}_{3}$ fold developed by $\mathrm{E}-\mathrm{W}$ shortening has its maximum effect along the eastern margin of the Champaner Group by closing up of domes at Narukot and Poyli areas (locations in figure 2a).

In order to postulate the possible causes of the fold trends recorded from the Champaner Group, the proto-continent accretion concept (primarily given by Naqvi et al. 1974; Radhakrishna and Naqvi 1986; Rogers 1986; Naqvi and Rogers 1987) for the Aravalli, the Dharwar and the Singhbhum proto-continents proved to be useful. The 'Y'-shaped lineaments, viz., the Narmada, Son and Godavari, along which the Aravalli-Dharwar, the Aravalli-Singhbhum and the Dharwar-Singhbhum proto-continents accreted, respectively, during the Meso-Proterozoic times. Based on a 'Working Model' or 'Working Hypothesis' given by Mamtani et al. (2000) in terms of deformation pertaining to the SAMB it clearly suggests that, there is an impact of accretionary event on southern part of the Aravalli proto-continent the manifestation of which is in the form of changes in the structural trends and growth of metamorphic minerals. Further the model illustrates that the E to NW trending structures in SAMB formed suturing between the Aravalli and the Dharwar Protocontinents (ca. 1400-935 Ma). In case of the present study, the N-S to NNE-SSW shortening direction generated on account of the suturing has led to the development of ESE-WNW to E-W trending structures across the Champaner Group. Furthermore, the area located at the core of the 


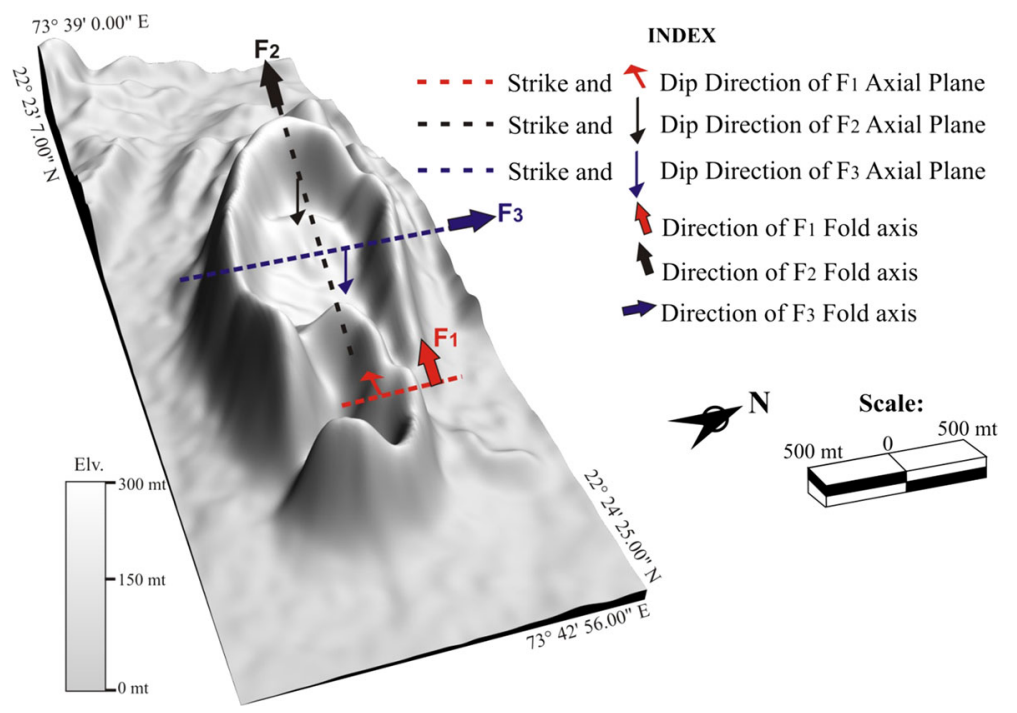

Figure 4. SRTM-derived shaded relief map of the Narukot Hammer head anticlinal structure. Respective orientations of the axial planes and fold axis have been demarcated.

Champaner Group has experienced intense compression due to regional deformation, engendering refolding of earlier folds at the Narukot dome and imparting westerly plunge to $F_{1}$ and $\mathrm{F}_{2}$ folds (figure 5a). Similar concept of protoplate tectonics has been anticipated to explain the deformational patterns observed in the southern parts of the Delhi Fold Belt (by Sychanthavong and Desai 1977; Sychanthavong and Merh 1981, 1985; Sychanthavong 1990).

Granites located in and around the Champaner Group of rocks display signatures of syn to postplutonic emplacement (Joshi and Limaye 2018). Distinguishing characteristic of syn/post-tectonic granite can be very well appreciated along the east of the Jhand area (location presented in figure 2a), where coarse-grained post-tectonic granite is having intrusive relationship with the finegrained syn-tectonic granite (figure 3i) (Joshi and Limaye 2014). The coeval pulse of granite emplaced during progressive deformation has magnetic foliation trending WNW-WSW (figure 1b). Feldspar laths within syn-tectonic granites too trend WNW to W striking trends (Mamtani 1998; Mamtani et al. 2002; Mamtani and Greiling 2005; Sen and Mamtani 2006). Existing geochemical records of syn-tectonic granite suggest that the granite is of 'S-type' evolved on account of partial melting of the continental crust during continent-continent collision (figure 5a) (Merh 1995; Goyal et al. 1997).

The granite of post-tectonic nature is characterised by forceful emplacement deforming the country rocks along $\mathrm{N}-\mathrm{S}$ trend and developed strike slip faults of sinistral/dextral nature along pre-existing axial planar weak zones throughout the group (figures $2 \mathrm{a}$ and $5 \mathrm{~b}$ ). The model given by $\mathrm{He}$ et al. (2009) for Fangshan pluton, SW Beijing, forms the rim syncline along the margin of the pluton. Similar style of N-S trending rim synclines is found to be developed along the eastern margin of the Champaner Group bordering the pluton. SRTM-derived shaded relief map of the Champaner region demarcates folded metasediments and its relationship with the adjacent pluton (figure 6). The post-tectonic granite having the geochemical affinity of 'A-type' representing transitional or post-orogenic uplift (suggested by Maithani et al. 1998 and Goyal et al. 2001), has been intruded by accommodating the space within the Champaner metasediments and pre-existing syn-tectonic pulse (figure 5b). Such inference has been derived by collecting xenolith evidence of (i) Champaner metasediment and (ii) fine-grained granite from coarse-grained granite variety (figure $3 \mathrm{j}-\mathrm{k})$. One such location is at the northeastern fringe of the Champaner region near Sukhi dam, where intrusive contact between Godhra granite and Champaner metasediments is exposed (figure 31).

Geophysical studies carried out by Joshi et al. (2018) using Microtremor method suggests pluton hump exactly below the Narukot dome. The surface manifestation of pluton hump can be corroborated by the development of the crosssectional reverse shear having top-to-east shear 


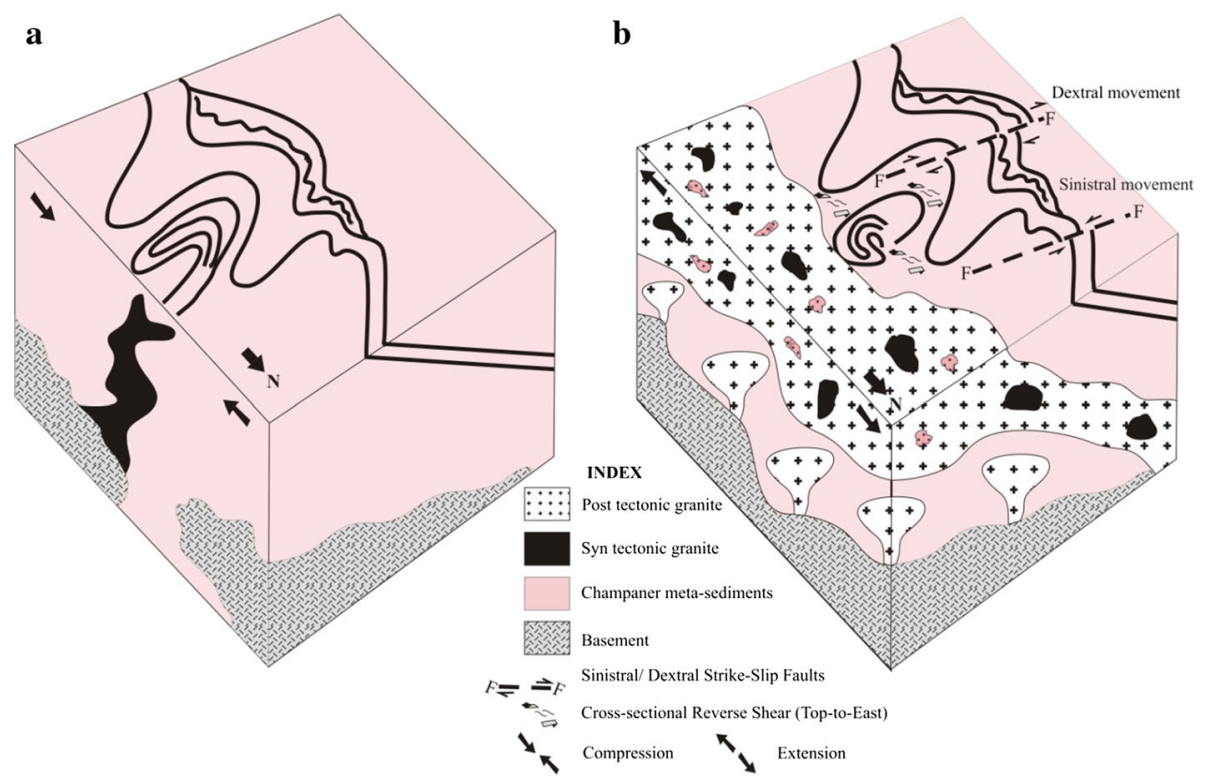

Figure 5. (a) Cartoon showing suturing of proto-continents and refolding of earlier folds along with the plunge on account of regional deformation as well as emplacement of syntectonic granite; (b) closing up of earlier refolded folds orthogonally and development of sinistral/dextral faults along the pre-existing axial planes due to post-intrusive pulse. Granite of posttectonic nature holds xenoliths of Champaner metasediments and earlier syn-tectonic granite. These cartoons have been modified after Winter (2012).

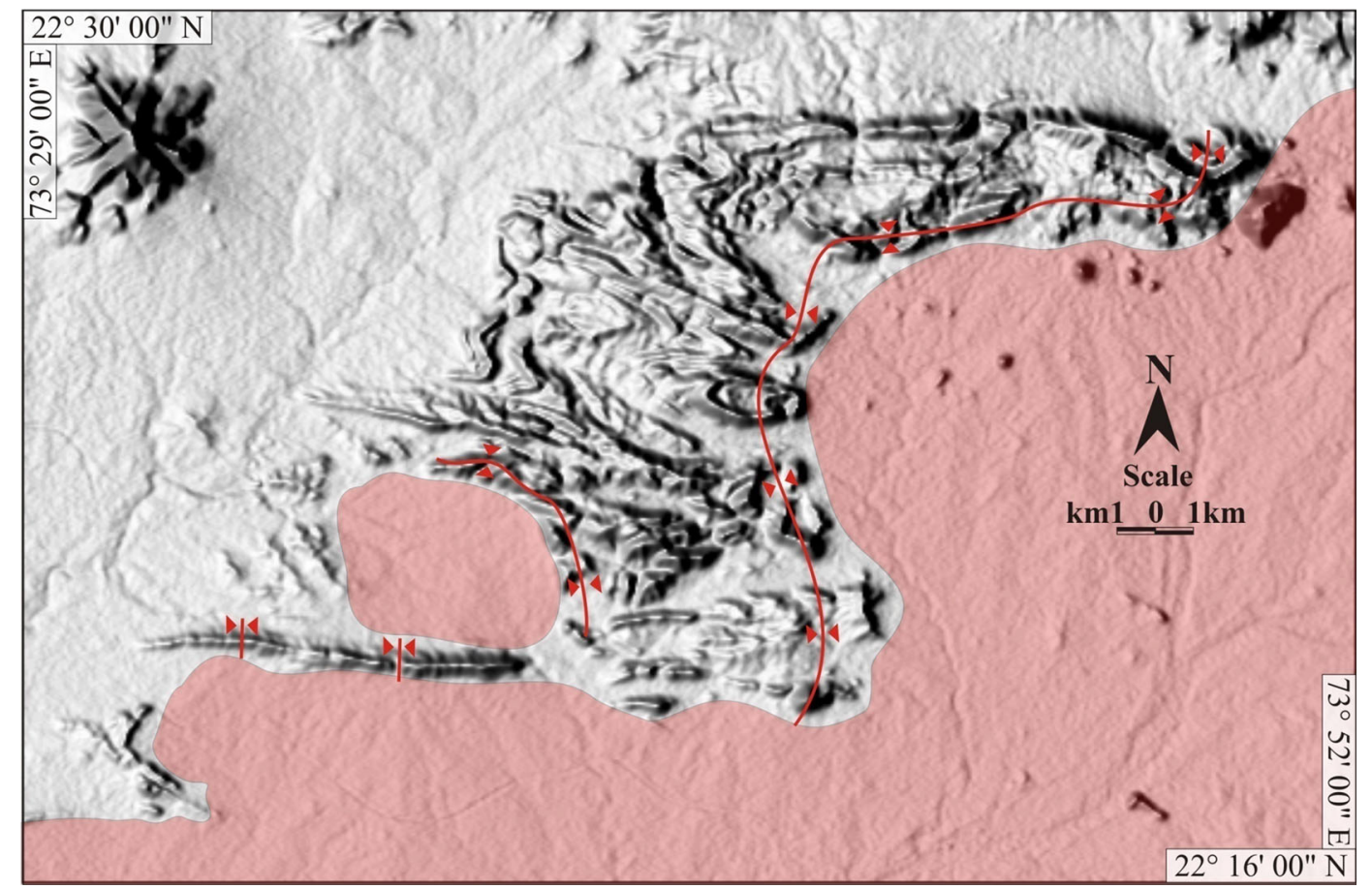

Figure 6. SRTM-derived shaded relief map of the Champaner region. Red region demarcates the granite country and shades of grey depict the folded Champaner metasediments. Curved thin red line shows the axial trace of the rim synclines developed along the periphery of the granite pluton.

sense, in the vicinity of the Narukot dome (figure $3 \mathrm{~m}-\mathrm{p}$ ). Recent work carried out by Joshi and Limaye (2018) at Jothwad region on isolated calc-silicate bands from khandia Formation records signatures of out-of-sequence deformation due to post-tectonic granite. The Jothwad region, part of the Champaner Group, represents superimposition of Type-II interference pattern over cylindrical 
Table 2. Summarisation of various interference fold patterns along with the fold and fault events observed within the Champaner Group (data of out-of-sequence deformation is after Joshi and Limaye 2018).

\begin{tabular}{|c|c|c|c|c|}
\hline \multicolumn{2}{|c|}{ Intrusives } & Deformation & \multicolumn{2}{|c|}{ Interference Fold Patterns and Fault Events } \\
\hline \multirow{5}{*}{ 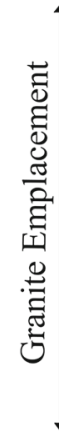 } & \multirow[b]{3}{*}{ Syn } & \multirow[b]{3}{*}{ Regional } & In Sequence & Out-of-Sequence \\
\hline & & & \multirow{2}{*}{$\begin{array}{l}\quad \text { Type-III } \\
\text { F1 } \sim \text { ESE-WNW; } \\
\text { F2 } \sim \text { E-W Plunging } \\
\text { Folds }\end{array}$} & $\begin{array}{c}\text { Cylindrical Upright } \\
\text { Fold }\end{array}$ \\
\hline & & & & $\begin{array}{l}\text { F1 } \sim \mathrm{NW}-\mathrm{SE} \\
\text { to } \mathrm{N}-\mathrm{S}\end{array}$ \\
\hline & & & Type-I & Type-II \\
\hline & Post & $\begin{array}{l}\text { Granite } \\
\text { Induced }\end{array}$ & $\begin{array}{l}\text { F3 N-S; } \\
\text { Sinistral/ Dextral Faults; } \\
\text { Cross-sectional reverse } \\
\text { shear (top-to-east) }\end{array}$ & $\mathrm{F} 2 \sim \mathrm{NE}-\mathrm{SW}$ \\
\hline
\end{tabular}

upright fold. Moreover, these interference fold patterns are rootless and depict no continuity in the subsurface as well as are unmatched with the existing structural set up of the Champaner Group.

\section{Conclusions}

- The Meso-Proterozoic Champaner Group represents interference fold patterns ranging from Type-1 to Type-III (table 2).

- Type-III interference fold pattern is due to regional deformation and generated by combinations of $\mathrm{F}_{1-2}$ folds $\left(\mathrm{F}_{1} \sim \mathrm{ESE}-\mathrm{WNW}\right.$; $\left.\mathrm{F}_{2} \sim \mathrm{E}-\mathrm{W}\right)$.

- Regional deformation has imparted westerly plunge to $\mathrm{F}_{1-2}$ folds and also characterised by syn-tectonic emplacement of granite having similar trend.

- Type-I interference pattern superimposed over Type-III by closing up of domes, represents $\mathrm{F}_{3}$ folds $\left(\mathrm{F}_{3} \sim \mathrm{N}-\mathrm{S}\right)$ due to post-intrusive granite. The same has been responsible for the development of sinistral/dextral faults throughout the group and cross-sectional reverse shears in vicinity of the Narukot dome.

- Type-II superimposed over rootless cylindrical upright folds represents out-of-sequence deformation of $\mathrm{F}_{1-2}$ folds $\left(\mathrm{F}_{1} \sim \mathrm{NW}-\mathrm{SE}\right.$ to $\mathrm{N}-\mathrm{S} ; \mathrm{F}_{2} \sim$ NE-SW) suggests syn-post plutonic emplacement.

\section{Acknowledgements}

The author wants to thank Prof L S Chamyal, Head, Department of Geology, The M S University of Baroda, Gujarat, for providing necessary facilities and continuous encouragement. The author would like to express his deep gratitude to his PhD guide Prof Manoj A Limaye for his tremendous support and for sharing his ideas about the terrain. Valuable discussion with Prof Bhushan $\mathrm{S}$ Deota is duly acknowledged. Author expresses his deep sense of gratitude to the Editor-in-Chief, Prof N V Chalapathi Rao and Prof Saibal Gupta (Corresponding editor). The review comments by Prof A Manish Mamtani (IIT, KGP) and anonymous reviewer helped the author to improve the quality of the text.

\section{References}

Caritg S, Burkhard M, Ducommun R, Helg U, Kopp L and Sue C 2004 Fold interference patterns in the Late Palaeozoic Anti-Atlas belt of Morocco; Terra Nova 16 27-37.

Das S 2003 Deformation and metamorphic history of the precambrian rocks in north-eastern part of Vadodara district, Gujarat with a reference to the stratigraphy and tectonics; Unpubl. PhD Thesis, The M. S. University of Baroda, Vadodara, pp. 1-110.

Das S, Singh P K and Sikarni C 2009 A preliminary study of thermal metamorphism in the Champaner Group of rocks in Panchmahals and Vadodara districts of Gujarat; Indian J. Geosci. 63 373-382.

Forbes C J and Betts P G 2004 Development of type 2 fold interference patterns in the Broken Hill Block: Implications for strain partitioning across a detachment during the Olarian Orogeny; Aust. J. Earth Sci. 51 173-188.

Forbes C J, Betts P G and Lister G S 2004 Synchronous development of type 2 and type 3 fold interference patterns: Evidence for recumbent sheath folds in the Allendale Area, Broken Hill, NSW, Australia; J. Struct. Geol. 26 113-126.

Fossen H 2016 Structural Geology; Cambridge University Press, London, pp. 1-456. 
Fossen H and Holst T B 1995 Northwest-verging folds and the northwestward movement of the Caledonian Jotun Nappe, Norway; J. Struct. Geol. 17 1-16.

Ghosh S K 1993 Structural Geology - Fundamentals and Modern Developments; Pergamon Press, Elsevier.

Gopalan K, Trivedi J R, Merh S S, Patel P P and Patel S G 1979 Rb-Sr age of Godhra and related granites, Gujarat; Proc. Indian Acad. Sci. 88A 7-17.

Gopinath K, Prasad Rao A D, Murty Y G K and Krishnaunni K K 1977 Precambrian of Baroda and Panchmahals, Gujarat. Elucidation of stratigraphy and structure; Rec. Geol. Surv. India 108 60-68.

Goyal N, Varughese S K, Hansda P K, Ramachandran S and Singh R 1997 Geochemistry of granites of Jambughoda, Panchmahals district, Gujarat and uranium mineralization in Champaner Group; J. Geol. Soc. India $\mathbf{5 0}$ $769-778$.

Goyal N, Pant P C, Hansda P K and Pandey B K 2001 Geochemistry and Rb-Sr age of the late Proterozoic Godhra granite of central Gujarat, India; J. Geol. Soc. India 58 391-398.

Gupta S N, Arora Y K, Mathur R K, Iqbaluddin, Prasad B, Sahai T N and Sharma S B 1980 Lithostratigraphic map of Aravalli region, southern Rajasthan and North Eastern Gujarat; Geol. Surv. India, Hyderabad.

Gupta S N, Mathur R K and Arora Y K 1992 Lithostratigraphy of Proterozoic rocks of Rajasthan and Gujarat - A review; Rec. Geol. Surv. India 115 63-85.

Gupta S N, Arora Y K, Mathur R K, Iqbaluddin, Prasad B, Sahai T N and Sharma S B 1995 Geological map of the Precambrians of the Aravalli region, southern Rajasthan and Northeastern Gujarat, India; Geol. Surv. India Publ., Hyderabad.

Gupta S N, Arora Y K, Mathur R K, Iqbaluddin, Prasad B, Sahai T N and Sharma S B 1997 The Precambrian geology of the Aravalli region, southern Rajasthan and NE Gujarat; Mem. Geol. Surv. India 123 1-262.

He B, Xu Y G and Paterson S 2009 Magmatic diapirism of the Fangshan pluton, southwest of Beijing, China; J. Struct. Geol. 31 615-626.

Jambusaria B B 1970 Geology of the area around Shivrajpur, dist. Panchamahals, Gujarat with special reference to the stratigraphy, structure and metamorphism; Unpubl. PhD Thesis, The M. S. University of Baroda, Vadodara, pp. 1-269.

Jambusaria B B and Merh S S 1967 Deformed greywacke conglomerates of Jaban near Shivrajpur, Panchmahals district, Gujarat; Indian Miner. 8 6-10.

Joshi A U and Limaye M A 2014 Evidence of syndeformational granitoid emplacement within Champaner Group, Gujarat; J. Maharaja Sayajirao Univ. Baroda 49 45-54.

Joshi A U and Limaye M A 2018 Rootless calc-silicate folds in granite: An implication towards syn to post plutonic emplacement; J. Earth. Syst. Sci. 127(5) ID67.

Joshi A U, Sant D A, Parvez I A, Rangarajan G, Limaye M A, Mukherjee S, Charola M J, Bhatt M N and Mistry S P 2018 Sub-surface profiling of granite pluton using microtremor method: Southern Aravalli, Gujarat, India; Int. J. Earth Sci. 107 191-201.

Karanth R V and Das S 2000 Deformational history of the pre-Champaner gneissic complex in Chhota Udepur area, Vadodara district, Gujarat; Indian J. Geol. 72 $43-54$.

Limaye M A 2016a An overview on crenulation cleavages from Narukot region, Champaner Group, Gujarat; J. Maharaja Sayajirao Univ. Baroda 50 1-7.

Limaye M A 2016b Unfolding the time relationship of structural events through LandSat Data: A case study from Khandia Formation, Champaner Group, Gujarat; J. Geomatics 10(1) 24-28.

Limaye M A and Bhatt H J 2013 Finite strain calculation on meta-conglomerate from westerly plunging Koba-Rustampura anticlinal fold, Champaner Group, eastern Gujarat; Gond. Geol. Mag. 28(1) $17-20$.

Maithani P B, Rathaiah Y V, Varughese S K and Singh R 1998 Granites of Zoz area, Baroda District, Gujarat and its economic significance; J. Geol. Soc. India $\mathbf{5 1}$ 201-206.

Mamtani M A 1998 Deformational mechanisms of the Lunavada pre-Cambrian rocks, Panchmahal district, Gujarat; Unpublished PhD Thesis, M.S. University of Baroda (India), 268p.

Mamtani M A 2014 Magnetic fabric as a vorticity gauge in syntectonically deformed granitic rocks; Tectonophys. 629 189-196.

Mamtani M A and Greiling R O 2005 Granite emplacement and its relation with regional deformation in the Aravalli Mountain Belt (India) - Inferences from magnetic fabric; J. Struct. Geol. 27 2008-2029.

Mamtani M A, Karanth R V, Merh S S and Greiling R O 2000 Tectonic evolution of the Southern part of Aravalli Mountain Belt and its environs - Possible causes and time constraints; Gond. Res. 3 175-187.

Mamtani M A, Merh S S, Karanth R V, Merh S S and Greiling R O 2001 Time relationship between metamorphism and deformation in Proterozoic rocks of the Lunavada region, southern Aravalli Mountain Belt (India) - A microstructural study; J. Asian Earth Sci. 19 195-205.

Mamtani M A, Karmakar B and Merh S S 2002 Evidence of polyphase deformation in gneissic rocks around Devgadh Bariya: Implications for evolution of Godhra Granite in the southern Aravalli region (India); Gond. Res. 5 401408.

Merh S S 1995 Geology of Gujarat; Geol. Soc. India Publ. Bangalore, 244p.

Naqvi S M and Rogers J J W 1987 Precambrian Geology of India; Oxford University Press, Inc., 223p.

Naqvi S M, Divakar Rao V and Narian H 1974 The Protocontinental growth of the Indian shield and the antiquity of its rift valleys; Precamb. Res. 1 345-398.

Patel D, Joshi A U and Limaye M A 2016 Sequential development of microstructures in quartzites of Champaner Group, Gujarat; J. Geophys. Res. 1(2) 101-104.

Platt J P 1983 Progressive refolding in ductile shear zones; J. Struct. Geol. 5 619-622.

Radhakrishna B P and Naqvi S M 1986 Precambrian continental crust of India and its evolution; J. Geol. 94 $145-166$.

Ramsay J G 1962 Interference patterns produced by the superposition of folds of "similar" type; J. Geol. 60466 481. 
Ramsay J G and Huber M I 1987 The Techniques of Modern Structural Geology; Vol. 2, Folds and Fractures, Academic Press, London.

Rogers J J W 1986 The Dharwar craton and the assembly of Peninsular India; J. Geol. 94 129-143.

Roy A B 1985 Tectonic and stratigraphic framework of the early precambrian rocks of Rajasthan and Northern Gujarat; Bull. Geol. Min. Met. Soc. India 55 100-114.

Roy A B 1988 Stratigraphic and tectonic framework of the Aravalli mountain range; In: Precambrian of the Aravalli mountain, Rajasthan, India (ed.) Roy A B, Geol. Soc. India Memoir 7 3-31.

Sen K and Mamtani M A 2006 Magnetic 1 fabric, shape preferred orientation and regional strain in granitic rocks; J. Struct. Geol. 28 1870-1882.

Shah A N, Karanth R V and Barot S A 1984 Geology of the area around Khandia with special reference to the Lead mineralisation, dist. Baroda, Gujarat; In: Proceedings of the 5th session Indian Geological Congress, pp. 127-133.

Srikarni C and Das S 1996 Stratigraphy and sedimentation history of Champaner Group, Gujarat; J. Indian Assoc. Sedim. 15 93-108.

Sychanthavong S P H 1990 Destructive plate margin tectonics in the evolution of the Delhi Precambrian fold belt and base metal deposits, western India; In: Crustal evolution and orogeny (ed.) Sychanthavong S P H, Oxford and IBH Publ. Co. Pvt. Ltd., New Delhi, pp. 101-158.

Corresponding editor: SAIBAL GUPTA
Sychanthavong S P H and Desai S D 1977 Proto-plate tectonics controlling the Precambrian deformations and metallogenetic epochs in northwestern Peninsular India; Miner. Sci. Eng. 9 218-236.

Sychanthavong S P H and Merh S S 1981 Protoplate tectonics: The energetic model for the structural, metamorphic and igneous evolution of the Precambrian rocks, northwestern peninsular India; In: Proc. SYMPET, Geol. Surv. India Sp. Publ., pp. 419-457.

Sychanthavong S P H and Merh S S 1985 Role of protoplate movement in the geological evolution of the Precambrian terrain of northwest peninsular India; In: Proceedings of the symposium on megastructures and plate tectonics and their role as a guide to ore mineralizations, Geol. Min. Met. Soc. India 53 124-146.

Tian Z, Xiao W, Shan Y, Windley B, Han C, Zhang J and Song D 2013 Mega-fold interference patterns in the Beishan orogen (NW China) created by change in plate configuration during Permo-Triassic termination of the Altaids; J. Struct. Geol. 52 119-135.

Winter J D 2012 Principles of igneous and metamorphic petrology (2nd edn), Pearson Prentice Hall, USA, $702 \mathrm{p}$.

Yellur D D 1969 Lead-zinc mineralisation in the Champaner rocks of Khandia, Baroda dist., Gujarat, India; Eco. Geol. 69 677-682. 